\title{
Implementation Of The Sale And Purchase Agreement And The Status Of Ownership Of Land Rights At Apartment In Payon Amartha View Of Semarang
}

\author{
Riska Fauziana ${ }^{1}$, Rizal Anugrah Bachriar $^{2}$ and Anis \\ Mashdurohatun $^{3}$
}

Abstracts. The study entitled "Implementation of the Sale and Purchase Agreement and the Status of Ownership of Land Rights at Apartment in Payon Amartha View of Semarang" aims to: 1) Understand the process of buying and selling apartments. 2) To know about the status of ownership of land rights of the apartment.

Theresearch method in this journal uses a sociological Juridical approach with the specification of the data collection method to Obtain the data that will be used as the thesis of material through an interview with the manager and the marketing of apartment in Payon Amartha View of Semarang, or by observation in the form of roomates surveillance systematically Involved in Obtaining data. Afterwards will be conducted analysis of the data Obtained from various sources.

The results of the research indicate that: 1) The process of buying and selling apartments begins with payment of the Booking Fee Followed by the signing of the Temporary Deed of Sale and Purchase (TDSP) as a legitimate and strong evidence that it has made a sale and purchase. 2) The ownership status of the buyer of the apartment is the Strata Title Certificate.

Keywords: Sale And Purchase; Ownership Rights To The Apartment.

\section{Introduction}

The increasing development of the citizens in Indonesia, increasing also the land requirements for the survival of a society. With public demand for land, even encourage increased trading activities of so many people capture new business opportunities by choosing to engage in buying and selling land and houses, to grow and develop the company whose main activity as developers of housing and residential areas, known by the public as a company developer or real estate. ${ }^{4}$

Housing and settlement development carried out by the developer, embodied with many built housing, flats and apartments. Flats are multi-store buildings, which can be inhabited together, where units of a unit in the building in question can be owned separately, which built both horizontally and vertically.

Flat development is aimed at the middle to lower conducted through the purchase, either in cash or on credit. Where the ownership status in the form of individual ownership of the apartment unit which includes the right along the top of the building, and land, which is regulated in Act No. 20 of 2011 on the Flats. It is as stated in Article 1 (4), (5) and (6) of Act No. 20 of 2011, namely:

\footnotetext{
${ }^{1}$ Student Master of Notary, Faculty of Law, Sultan Agung Islamic University Semarang E-mail: rzkfzna@gmail.com

2 Students of Master of Law, Faculty Of Law, Universitas Islam Sultan Agung email rizalanugrahbachriar@gmail.com

${ }_{3}^{3}$ Faculty of Law Universitas Islam Sultan Agung

${ }^{4}$ Sahat H.M.T. Sinaga, Jual Beli Tanah dan Pencatatan Peralihan Hak, Bandung: Pustaka Sutra, 2007, p.1.
} 
4. The land together is a piece of land rights or land lease for a building that is used on the basis of common rights are not separate upon standing flats and set its limit in terms of building permits.

5. The joint is part-owned flats are not separately for use together in unity with the functions of the units of flats.

6. The shared objects are objects that are not part of flats but jointly owned parts are not separate for sharing.

However, as the development of more advanced age and modern, flats altered by the presence of the apartment. The apartment is the residence consists of a sitting room, bedroom, bathroom, kitchen which is at a multi-store building floor are large and luxurious, equipped with various facilities such as swimming pool, fitness center, shops and so on. ${ }^{5}$

Shape is no different apartment buildings with flats, both of them have in common is owned separately because the built horizontally and vertically. The only difference is visible in the interior design, where the flats just like a makeshift home in the apartment while the design follows the developments with a more luxurious design. Although the apartment is a luxury building, but its presence is pretty much in demand by various groups. Especially for the middle class and above, choosing an apartment as their second home, which is where ownership can be done by buying and selling.

In the Code Article 1457 Civil Code explains that buying and selling is an agreement by which one party to bind himself to hand over the goods, and the other party to pay the promised price.

Sale and purchase is considered to have occurred between the two parties when they reached agreement on the traded items for sale and the price, even though the object has not been submitted and the price is also unpaid. ${ }^{6}$

The sale and purchase of apartments due to an agreement between sellers and buyers of apartments are usually referred to the purchase agreement. Act has defined the terms validity of a treaty, it can be seen in Article 1320 of the Civil Code which an agreement is considered valid must meet the following requirements:

- The existence of an agreement of both parties.

- Skills or maturity to yourself that contract.

- Should be about the subject or object.

- Basic reason or causal allowed.

Implementation of buying and selling land and building in this regard is the apartment building, should qualify:

- The buildings that by their nature are incorporated by reference into the soil.

- That holders of rights over the land, the owner of the building.

- In the deed of sale purchasing explicitly stated that the object sold is purchasing land and building rights.

\footnotetext{
${ }^{5}$ Indonesian Dictionary, p.45

${ }^{6}$ Effendi Perangin, Hukum Agraria di Indonesia, Jakarta: Rajawali Pers, 1991, p.14.

7 Yahya Harahap, Segi-Segi Hukum Perjanjian, Bandung: Alumni, 1986, p.24.

${ }^{8}$ Sahat H.M.T. Sinaga, Jual Beli Tanah dan Pencatatan Peralihan Hak, Bandung: Pustaka Sutra, 2007, p.22.
} 
In order to clarify that the existing problems will be addressed more directly and in accordance with the objectives and the expected goals, it is imperative to formulate the issues to be discussed. The formulation of the problem to be addressed in this study are: How the implementation process of buying and selling apartments in Payon Amartha View of Semarang? How the status of land ownership apartments in Payon Amartha View of Semarang?

\section{Research methods}

The approach used in this study discusses the problem is empirical juridical approach. Empirical jurisdiction is a legal research methods that attempt to view the law in terms of real or can be said to see, examine, how the working of the law in society ${ }^{9}$.

In this case the juridical approach is used to analyze various regulations on the sale and purchase of apartments, whereas the empirical approach used to analyze the legal views of the behavior of people in public life, always interacting and relating with the community aspects ${ }^{10}$.

Specifications required in this research is descriptive analysisa study that attempted to describe the legal issues, the legal system and to study it or analyze it according to the needs of the research in question. While Descriptive itself means that this study aims to describe comprehensively and systematically about the sale and purchase of apartments. While analytical means grouping, connect, compare and give meaning aspects in the implementation process of buying and selling apartments. To obtain information along with the data that is accurate, relevant and related to the issue and the completion of the writing of this journal, the authors conducted research in Apartment Payon Amartha View of Semarang, and the subjects in this study is the Marketing Manager of Apartment Payon Amartha View of Semarang.

\section{Results and Discussion}

\subsection{Implementation Process Purchase Apartment in Payon Amartha View of Semarang}

According to Minister of State 91995 apartment units are still in the process of development can be marketed through the booking system by way of a preliminary sale and purchase (booking) through a purchase agreement apartment units.

At the time of the booking, interested buyers can receive and sign a letter prepared by the company orders the construction of which contains:

- And the name or number of buildings and apartment units were booked

- Floor number and type of apartment units

- Spacious apartment units

- The selling price of the apartment units

\footnotetext{
${ }^{9}$ Cholid Narbuko dan H. Abu Achmadi, Metodologi Penelitian, (Jakarta: PT.Bumi Aksara, 2002), p 14

10 Bambang Sunggono, Metodologi Penelitian Hukum, (Jakarta: PT.RAJA GRAFINDO PERSADA, 2003), p.43
} 
- The provision of advance payments

- building specifications

- Date of completion of construction of flats

- Provisions concerning the statement and consent to accept the terms and conditions set out and sign the documents prepared by the company's development.

As for his legitimate Terms of the purchase agreement according to Article 1320 of the Civil Code are:

- They agreed that bind himself

- Ability to create an engagement

- A certain thing

- A cause that kosher

Meanwhile, according to Mr. Donny Oktaviano as a marketing manager at the apartment Payon Amartha View of Semarang implementation of the sale and purchase of apartments in Payon Amartha View of Semarang this can be done through the following methods of payment on credit, payment by full payment or cash, and payment by gradually.

Before carrying out the sale and purchase of apartments purchaser must make payment early booking fee or booking fee. Booking fee is evidence of the seriousness of the buyer to buy an apartment and pay the booking fee with the buyer is entitled to choose an apartment unit which will be purchased and the developer is obliged to block the apartments of the other party offer.

Developer of apartment in Payon Amartha view of Semarang is always a precondition to the buyer to pay the booking fee before proceeding to the next transaction. The magnitude of between 5 million to 10 million, depending on the small of her value of the selected unit. It is this process which is the way developers binding purchase agreement early by giving Numbers-Sort Buy (Nub) and the buyer signed a Sale and Purchase Agreements Forms Temporary (AJBS). ${ }^{11}$

Dana booking fee payments can not be retracted if we canceled purchase such apartments, these funds will be allocated at a price so apartments that will be purchased by the buyer.

Stages of buying and selling apartments next is payment Down Payment (DP) and commonly known as a cash advance. That portion of payments made on the initial purchase, while the rest will be paid later. The amount is usually around $30 \%$ of the price of the apartment units.

In this process the developer will ask the completeness of the letters and the data buyer in order at Make a Treaty Sale and Purchase Agreement (SPA) between sellers and buyers, down payment will be followed by the signing of the Sale and Purchase Agreement (SPA), among other things the extent of remaining payments, settlement date and sanctions. This is in accordance with Article 43 UURS No.20 of 2011 which states that:

(1) The process of buying and selling flat completed before construction of flats can be done via the SPA were made before a notary public.

(2) SPA referred to in paragraph (1) shall be conducted after fulfilling the

${ }^{11}$ Interview with Mr. Donny Oktaviano as a marketing manager on 2 November 2017 
requirements of certainty on:
a. status of land ownership;
b. IMB ownership;
c. availability of infrastructure, facilities, and public utilities;
d. built at least $20 \%$ (twenty percent);
e. terms of the agreement;

Down Payment (DP) is different from the booking fee. If the booking fee only for reservation payment on the apartment units, while Down Payment (DP) is the first payment or payment in advance of the transaction value. Both the fixed payments are allocated to the prices so the apartment units.

The next steps depend on the choice of payment methods, namely by way of credit, payment by full payment or cash, and payment by gradually. Which will be explained more clearly as follows:

- Payment by Credit

In this method of making a payment Booking Fee and the down payment, the buyer must complete the documents requested by the Bank Credit, if the bank's credit has been approved and the funds from the bank loan would be disbursed and has been handed over to the apartment we then do a sale and purchase agreement in notary together with developers and Credit Bank.

- Full payment by Payment or cash

In this method, after making a Booking Fee payment and down payment, the buyer must pay the apartment unit by way of cash or transfer, if the transfer of the deposit slip shall be reported in apartment sales office Payon Amartha View of Semarang. Having declared fully paid by the developer then subsequently perform the contract of sale before a notary. Buyers of apartments that have paid off the apartment units it can proceed with the transition process Land rights preceded by completing a self-identity card and a copy of $\mathrm{KK}$ in order to proceed to the process of making the Sale and Purchase Agreements (AJB) and the transfer of rights to land before the Notary that will be discussed in next subchapter.

- Payment by gradually

In the apartment of Payon Amartha View of Semarang opened a savings program incrementally in order to settle the apartment, the stage of the settlement was divided into 6 with a period every 2 months for one year, can be through cash and transfer, if the transfer of the deposit slip should be reported in the sales office apartment Payon Amartha View of Semarang, after the buyer make a payment of 6 stages and declared fully paid by the developer, the status of the purchase is paid off. Payment 6 is the same stage as payment in full or full payment which distinguishes only process payment via installments through the program in the open by the apartment. Having declared fully paid by the developer then subsequently perform the contract of sale before a notary. Buyers of apartments that have paid off the apartment unit can proceed Land rights transition process begins with completing a self-identity card and a copy of KK in order to proceed to the manufacturing process and transition Sale and Purchase Agreements land rights before the Notary. 
The signing of the Sale and Purchase Agreements (AJB) is carried out when the buyer has paid the entire purchase price of the house or apartment units were bought. This is in accordance with the provisions of AJB in the Decree of the Minister of Housing No. 09 / KPTS / M / 1995 on Guidelines for the Sale and Purchase House (Kepmenpera), which states that the AJB must be signed by the seller and the buyer in the presence of Deed Official Land (PPAT), in terms of:

(i) houses have been completed and ready for occupation;

(ii) the buyer has paid the entire price of land and houses, as well as taxes and other costs associated; and

(iii) the application process Broking on the ground has been fully processed, and certified registered Broking on behalf of the seller.

A description of the Sale and Purchase Agreements (AJB), and its terms will be explained further in the next subchapter ie land rights transitional apartments.

\subsection{Status Ownership Rights to Land Apartments in Payon Amartha View of Semarang}

Apartments, condominiums, strata title, flats, all of it is the other name of flats. Because in Indonesia itself is only familiar with the term Flats, therefore remains subject to regulatory apartment flats, because the apartment is the commercial flats. Land ownership by UURS 20 apartments in 2011 under article 46 that:

1) The ownership of the property rights flat flat are individual separate from the collective rights over the parts together, a common good, and the land together.

2) Right to pieces together, a common good, and the land together as referred to in paragraph (1) shall be calculated based on the NPP (Proportional Comparison Value)

As many buyers ask Payon Amartha View of Semarang on apartment developers, namely what is the status of my property rights or certificates will I (the buyer) get when buying an apartment.

Based on the research results of the author to the apartment Payon Amartha View of Semarang according to Mr Donny as a marketing manager revealed that each buyer apartments in Payon Amartha View of Semarang will get a Certificate of Property Rights on Unit Housing Project (SHMSRS). Because the apartments are built on land of Payon Amartha View of Semarang Properties so it can be published on the Certificate Properties Unit Housing Project (SHMSRS) for the unit in her apartment. ${ }^{12}$

A buyer would have a certificate of ownership of apartments, here the buyer should be aware that Land Property Rights are different from Apartment Property Rights. If the apartment, then the property will be divided into three areas:

- Private Property (Unit Apartment)

- Together items (elevator, parking, Stairs, Swimming Pool, Fitness Center)

- Land Belongs Together

Certificates owned by the buyer apartment is not fully owned by the buyers of apartments, which became fully right is a unit of the apartment, while the land rights

\footnotetext{
${ }^{12}$ Interview with Mr. Donny Oktaviano as a marketing manager on 2 November 2017
} 
and collective goods do not belong to the buyer completely.

As evidence of ownership of the apartment units (apartments) will then be issued a certificate of ownership of the apartment units (SHMSRS) consisting of:

- Copies of the land book

- Measurement certificate over land rights along

- Drawings that level flats (apartments) are concerned, which shows the owned apartment units

Certificate of Property Rights on Unit Housing Project (SHMSRS) is the same as the house deeds in general which may be traded and can move right hand.

This is in accordance with article 47 UURS NO.20 of 2011 which reads:

- As proof of ownership of flat on land property rights, right to build, or the use rights on state land, building rights or rights of use over land management rights issued flat SHM.

- SHM flat referred to in paragraph (1) shall be issued for every person who qualifies as holders of land rights.

- SHM flat referred to in paragraph (1) constitutes an inseparable unit consisting of:

- Copies of books and letters land measuring over land rights along accordance with the provisions of the legislation;

- Pictures of floor plans in the relevant level bunk house that shows flat owned; and

- Descriptions about the large part of the right pieces together, a common good and for the relevant land together.

- SHM flat referred to in paragraph (1) shall be issued by the office of district / city land

- Flat SHM can be used as collateral with the encumbered encumbrance in accordance with the provisions of the legislation.

\section{Conclusion}

Based on what has been described in the previous section, it can be concluded as follows:

- Selling Process Buy Apartment in Payon Amartha View of Semarang, begin with the payment of funds booking fee for booking of the apartment unit, then continued with the payment Down Payment (DP) or advance, and continued with the repayment of the apartment units. Upon payment in full can continue the transition process Land rights Apartment

- The ownership status of land titles were obtained buyers of apartments in Payon Amartha View of Semarang is owned rights certificate on Unit Housing Project (SHMSRS) where the certificate together with the certificate of the house in general that can be traded and can move right hand.

\section{Bibliography}

[1] Harahap, Yahya. 1986. Segi-Segi Hukum Perjanjian. Bandung: Alumni.

[2] Kamus Besar Bahasa Indonesia 
[3] Kitab Undang-Undang Hukum Perdata

[4] Narbuko, Cholid. 2002. Metodologi Penelitian. Jakarta: PT. Bumi Aksara

[5] Perangin, Effendi. 1991. Hukum Agraria di Indonesia. Jakarta: Rajawali Pers. Sahat H.M.T. 2007 Sinaga, Jual Beli Tanah dan Pencatatan Peralihan Hak, Bandung: Pustaka Sutra.

[6] Soebekti.1989. Aneka Perjanjian. Bandung: Citra Aditya Bakti.

[7] Soekanto, Soerjono. 1993. Pengantar Penelitian Hukum, Jakarta: UIPress

[8] Sunggono, Bambang. 2003. Metodologi Penelitian Hukum, Jakarta: PT Raja Grafindo Persada

[9] Act No. 20 of 2011 on the Flats

[10] Act No. 01 of 2011 on Housing and Human Settlements Region 